\title{
PLATÃO, AL-FÂRÂBî E AVERRÓIS: \\ AS OUALIDADES ESSENCIAIS AO GOVERNANTE
}

Rosalie Helena de Souza Pereira*

RESUMO: A filosofia política que se desenvolveu no mundo islâmico, entre os séculos IX e XII, apropriou-se de conceitos da filosofia grega, principalmente de Platão e de Aristóteles. A República e as Leis, de Platão, e a Ética Nicomaqueia, de Aristóteles, foram os textos que fundamentaram as concepções políticas dos filósofos de expressão árabe, desde as virtudes a serem buscadas individualmente até a ideia do melhor regime político. Com base nos textos gregos traduzidos para o árabe, esses filósofos delinearam os objetivos da vida política e o modo como o regime político deveria ser estruturado para alcançá-los. A cidade ideal platônica é o paradigma a ser realizado. O tópico das qualidades essenciais ao soberano faz parte de uma longa tradição que remonta aos "espelhos dos príncipes" de origem persa; está presente também na tradição religiosa e no Direito islâmico. Dois grandes expoentes da filosofia de expressão árabe, Al-Fârâbî e Averróis, retomam o tópico das qualidades essenciais ao filósofo-rei, enunciado na República, e o adaptam a seu universo histórico ${ }^{1}$.

PALAVRAS-CHAVE: Platão. Al-Fârâbî. Averróis. Qualidades do soberano. Virtudes.

Sob a influência dos filósofos gregos, especialmente Platão e Aristóteles, os filósofos muçulmanos introduziram no Islã conceitos de filosofia política que não apenas refletem a Lei revelada e a vida nas comunidades islâmicas, mas também recuperam a tradição da filosofia política, cujo objetivo é a busca do melhor regime político, com ênfase na relação necessária entre o

* (Mestrado em Filosofia na FFLCH-USP; Doutorado em Filosofia no IFCH-UNICAMP; desde março de 2009, Estágio de Pós-Doutorado em Filosofia Medieval, Pontifícia Universidade Católica de São Paulo - PUCSP, sob a supervisão do Prof. Carlos Arthur Ribeiro do Nascimento). E-mail: rosaliepereira@uol.com.br

${ }^{1}$ Em versão resumida, apresentei uma comunicação sobre esse tema no IX Symposium Platonicum Plato's Politeia, cf. referências em Pereira (2010). 
regime político e a qualidade de vida que pode ser alcançada pelos seres humanos. A República e as Leis, de Platão, e a Ética Nicomaqueia, de Aristóteles, foram os textos que fundamentaram as suas concepções de uma cidade ideal, desde as virtudes a serem buscadas individualmente até a ideia do melhor regime político, ou seja, fundamentaram os objetivos da vida política e do modo como o regime político deveria ser estruturado para alcançá-los. Sobressaem nessa vertente Al-Fârâbî, Avicena (Ibn Sînâ) e Averróis (Ibn Rushd), embora Ibn Bâjjah (Avempace) e Ibn Tufayl tenham igualmente deixado contribuições significativas.

Entre os filósofos de expressão árabe, Al-Fârâbî é considerado o fundador da filosofia política. Chamado de "o segundo mestre", isto é, depois de Aristóteles, foi ele quem "[...] fez reviver a filosofia política platônica e elevou-a ao estatuto de disciplina que permite estudar a instauração das religiões reveladas e as sociedades nelas fundadas" (MAHDI, 2000, p. 12). O pensamento político de Al-Fârâbî influenciou tanto os filósofos muçulmanos que o sucederam, como os filósofos judeus, em particular Maimônides (STRAUSS, 1988).

Averróis, imortalizado como "O Comentador" da obra de Aristóteles, deixou um tratado sobre a República, seu único escrito dedicado a comentar uma obra platônica. Nessa obra, Averróis expõe suas ideias políticas, mas o faz de modo peculiar, uma vez que alguns trechos apresentam paráfrases da República e outros simplesmente mudam o conteúdo das passagens comentadas, para melhor se adaptarem à discussão das condições sociais e políticas da época.

Entre os árabes, uma das fontes possíveis do estabelecimento das qualidades necessárias para a designação de alguém ao cargo de califa procede da literatura árabe e constitui os "espelhos de príncipes" (specula principum). De origem persa, os "espelhos" retratam a arte de governar e o modelo de virtude imposto ao príncipe. Representam um gênero de literatura anterior à eclosão do Islã

Outra fonte possível desse tema consta no Direito islâmico (fiqh). A teoria do califado, como ficou conhecida, foi elaborada no século XI, durante o período de decadência do poder abássida, e tem como seu maior expoente o jurista Al-Mawardî (974-1058), que indica, em sua obra Os Estatutos do Governo, as sete condições exigidas para que um imã/califa seja eleito.

Na filosofia que se desenvolveu em terras do Islã, Al-Fârâbî e Averróis fazem uma releitura do tópico das qualidades essenciais ao filósofo-rei, que Platão enuncia na República, adaptando-o a seu tempo e lugar. 


\section{O filósofo-rei de Platão}

O ponto de partida da teoria do governante (rei)-filósofo é a discussão sobre a cidade ideal na República (II, 368 et seq.), no debate entre Sócrates e os sofistas, quanto à definição de justiça. Ao propor começar pela definição da justiça de um governo para então discorrer acerca da justiça de um homem (Rep. II, 368e), Platão assume que a definição da justiça tem sua base no princípio de que ela, como qualidade, pode existir tanto na comunidade como no indivíduo. Como é mais fácil saber o que é a justiça de um governo, o debate começa com a busca de uma definição da cidade justa para que, depois, o princípio dessa definição seja aplicado às ações dos indivíduos. Sócrates desenvolve uma teoria dos estágios de desenvolvimento da sociedade e, com isso, passa a discorrer sobre os diferentes estamentos sociais necessários para a convivência humana na cidade. Em República IV, 433a-b, Sócrates chega à definição de justiça, afirmando "[...] que cada um deve ocupar-se com a tarefa para a qual sua natureza é mais bem dotada [...] cumprir a tarefa que é a sua sem meter-se em muitas atividades" e, desse modo, sedimenta a estrutura social ideal baseada no tipo de trabalho que cada um exerce, a saber, os artesãos, os guardiões e os governantes (reis)-filósofos. Essa estrutura tripartite da sociedade é consoante com a estrutura tripartite da alma (Rep. IV, 441c), cujas partes são: a sede dos desejos (tò epithymetikón), a da impetuosidade (tò thymoeidés) e a da razão (tò logistikón). O epithymetikón é representado pelo povo, cuja função é prover a cidade de suas necessidades materiais. Os guardiões, cuja função é proteger a cidade contra os inimigos internos e externos, são representados pela parte da impetuosidade, e os filósofos, representados pela parte da razão, têm a função de governar a cidade, em virtude da perfeição de seu intelecto.

Do mesmo modo como a razão governa as partes inferiores da alma, os que são dotados de uma perfeição racional devem conduzir a sociedade organizada hierarquicamente. Cada estamento social deverá estar habilitado para a atividade que lhe é própria, e, de acordo com sua habilidade, cada indivíduo deve possuir as virtudes requeridas para desempenhar satisfatoriamente a sua função social. A cidade ideal, a que deve ser otimamente construída, deverá ser "[...] sábia, corajosa, moderada e justa" (Rep. IV, 427e). Justiça e moderação são virtudes que todos deverão ter. A justiça é feita quando cada um é reconhecido como necessário para e pelo conjunto social. A moderação, em sentido amplo, significa a pronta aceitação de cada um para assumir o seu próprio papel social e eliminar seus desejos pessoais, já que, na cidade ideal, cada um se dedica ao que melhor sabe fazer e reconhece as necessidades da sociedade como um todo. Por causa da especificidade de sua atividade, os guardiões devem ter uma virtude a mais, a coragem. O rei, que ocupa o posto mais elevado no governo ideal, 
deverá necessariamente possuir as virtudes dos estamentos inferiores, a saber, justiça, temperança e coragem. No entanto, deverá também ser dotado de sabedoria, o que faz dele a imagem exata do governante ideal, por meio das quatro virtudes cardinais. Com isso, Platão defende a tese de que é imprescindível que sejam os filósofos a governar ou que os reis e soberanos se tornem filósofos, porque somente o filósofo é dotado da quarta virtude, a sabedoria. Como, então, ser sábio e tornar-se um filósofo?

Na República, Platão discorre sobre as qualidades e/ou condições da alma filosófica em três níveis. Em primeiro lugar, o futuro filósofo deve ter o potencial necessário para tornar-se um filósofo; para isso, deve ser rápido no aprendizado e deve ser dono de uma boa memória. Em segundo lugar, uma vez munido dessas qualidades potenciais, o futuro filósofo deve desejar constantemente atingir a perfeição, por meio do conhecimento no domínio do eterno e do imutável, com seus desejos dirigidos apenas para as ciências, pois

[...] para aquele cujos desejos fluem na direção do conhecimento e de tudo que lhe é similar, o prazer seria só da própria alma, creio, e, quanto aos do corpo, ele os deixará de lado, se não for um falso, mas um verdadeiro filósofo. (Rep. VI, 485d-e) $)^{2}$.

Para Platão, o conhecimento verdadeiro é o conhecimento das ideias imutáveis e eternas. Este é o conhecimento que o filósofo deve desejar e buscar, este é o bem almejado. Em terceiro lugar, já que o desejo da perfeição, com esse conhecimento, conduz à perfeição também na realização das outras virtudes, aquele cujo desejo estiver dirigido para essa única direção, isto é, a do conhecimento verdadeiro, será desviado do desejo por outras coisas e, por conseguinte, será moderado em relação aos prazeres do corpo e aos prazeres materiais em geral, como, por exemplo, o amor pelo dinheiro. O filósofo que é um verdadeiro filósofo “[...] tem grandeza de alma, é magnânimo e dotado de graça, amigo e parente da verdade, da justiça, da coragem e da moderação" (Rep. VI, 487a). Desse modo, Platão "[...] combina as três qualidades básicas que são essenciais para o filósofo: o potencial para atingir a verdade, o desejo para atingi-la e a perfeição das virtudes morais e intelectuais" (MELAMED, 2003, p. 14).

Educado para desenvolver esses talentos e, com o tempo, tornando-se experiente e virtuoso, o filósofo é o único a quem se deve confiar o governo da cidade (Rep. VI, 487a-b). Quem quer que tenha atingido a perfeição moral e

\footnotetext{
${ }^{2}$ Platão sublinha que aquele que é amante do saber (philomathés) possui o desejo pelo saber, além de ser também inspirado pelo amor à verdade (Rep. V, 475c); desde a sua juventude, busca as ciências, e todos os seus desejos são conduzidos apenas nessa direção.
} 
intelectual tem não só a habilidade para governar a cidade, mas também a obrigação de conduzir seus concidadãos "[...] rumo ao bem". Quem melhor que o filósofo para proteger a cidade, posto que é o mais versado no conhecimento dos meios de administrá-la, o que possui as honras mais elevadas e o que leva uma vida melhor que a dos que administram a política? (Rep. VII, 521b) ${ }^{3}$.

Platão descreve a natureza do verdadeiro filósofo, a partir das condições necessárias aos que deverão "[...] estabelecer as leis, protegê-las e preserválas" (Rep. VI, 484d). Em República VI, 485a-487a, são enumeradas as qualidades do futuro governante-filósofo:

1. Ama a verdade e aspira à posse de toda verdade; "semelhante a uma torrente que não pode se desviar de seu curso natural", seu amor à ciência e à verdade absorve todos os desejos de sua alma.

2. Odeia a mentira e a fraude.

3. Segue os prazeres da alma e abandona os do corpo.

4. Moderado, permanece sempre afastado da cupidez de riquezas.

5. É generoso e magnânimo, entusiasta e desinteressado.

6. É corajoso e não teme a morte.

7. É dono de uma poderosa memória e de uma facilidade de aprendizado.

8. Possui uma força guiada pela justa medida e pela graça.

Ao concluir, Platão resume a discussão e reafirma as condições que, por natureza, são necessárias ao futuro filósofo-governante: ter uma boa memória; ser rápido para adquirir conhecimento; ser capaz de pensamentos grandiosos; ser dotado de elegância ou graça no pensar; ser amigo da verdade, da justiça, da coragem e da moderação (Rep. VI, 487a) .

Platão, todavia, concede uma alternativa aos reis empossados - ou seja, tornarem-se eles próprios filósofos, por meio de uma educação filosófica -, e é categórico ao fazer tal assertiva:

Se os filósofos não forem reis nas cidades ou se os que hoje são chamados reis e soberanos não forem filósofos genuínos e capazes, e se, numa mesma pessoa, não coincidirem poder político e filosofia [...] não é possível [...] que haja para as cidades uma trégua de males e, penso, nem para o gênero

\footnotetext{
${ }^{3}$ No mito da caverna (Rep. VII, 514a et seq.), Platão afirma que, dentre os prisioneiros, os que detinham o poder e eram aclamados com honra e glória eram os que mais agudamente sabiam discernir as sombras que se projetavam no muro diante deles (Rep. VII, 516b-d).

${ }^{4}$ Em Rep. VI, 490b-d, Platão repete as condições necessárias ao filósofo: amor à verdade e à ciência, abominação da mentira, moderação, coragem, magnanimidade, facilidade para aprender, boa memória; em Rep. VI, 491b, são mencionadas a coragem e a moderação; em Rep. VI, 494b, Platão alude à facilidade no aprendizado, uma boa memória, a coragem e a magnanimidade. Sobre as virtudes cardinais, ver Rep. IV, 427e: “[...] a nossa cidade, se corretamente fundada [...] será sábia, corajosa, moderada e justa", a primeira menção às quatro virtudes cardinais, temperança/moderação (sophrosýne), coragem (andreía), sabedoria (sophía) e justiça (dikaiosýne).
} 
humano. Nem, antes disso, na medida do que é possível, jamais nascerá e verá a luz do sol essa constituição de que falamos. (Rep. V, 473c-d) ${ }^{5}$.

Com isso, Platão conclui que a sociedade só será salva se governada por um filósofo, embora conceda aos reis a possibilidade de se tornarem filósofos por intermédio de uma educação apropriada. Sabe-se, no entanto, que Platão tentou em vão fazer de Dionísio II, tirano de Siracusa, um filósofo, como relatou na Carta VII.

\section{O soberano ideal de Al-Fârâbî}

No Livro sobre a Religião (Kitâb al-Milla), Al-Fârâbî define o "primeiro governante" (al-ra'îs al-awwal ${ }^{6}$ ) como aquele que promulga as regras que determinam e delimitam as opiniões ${ }^{7}$ e ações que constituem a religião (ALFÂRÂBÎ, 1992, p. 73; id., 2004² , p. 93). Se este governante for virtuoso, seu governo também será. Embora esse primeiro governante tenha determinado as regras iniciais das opiniões e ações constitutivas da religião que fundou, poderá ocorrer que não tenha tido a possibilidade de determiná-las exaustivamente, em razão de circunstâncias alheias à sua vontade, a saber, seja por sua morte prematura, seja por guerras e outros afazeres necessários, seja porque apenas determinou ações e opiniões para ocasiões e casos específicos que presenciara em vida. Como nem sempre os acontecimentos se repetem na mesma época e no mesmo lugar, muitos fatos deixam de receber uma legislação específica promulgada por esse primeiro governante (ALFÂRÂBÎ, 1992, p. 79; id., 2004², p. 98). Nesse caso, seu sucessor continuará a legislar. O primeiro governante, que já é virtuoso, estabelece pela primeira vez os modos de viver e os hábitos virtuosos, já que, antes dele, os habitantes da

\footnotetext{
${ }^{5}$ Ao propor a união da filosofia com a função política como único poder, Platão funde teoria e prática Segundo Georges Leroux, essa nova realeza idealizada por Platão rompe com o tipo de governo dos reis da história grega e pode-se questionar por que Platão concebe uma realeza como ideal de uma filosofia politicamente encarnada (cf. LEROUX, in: PLATÃO, 2004², p. 639-640, nota 101).

${ }^{6}$ Conforme Charles E. Butterworth, o "primeiro governante" (al-ra'îs al-awwal) não é necessariamente o primeiro no tempo. Poderia tratar-se do supremo governante, isto é, do fundador da religião, como também de seu sucessor imediato, que, porém, deve ter o poder de legislar (BUTTERWORTH, in: ALFÂRÂBÎ, 2004², p. 93, nota 1). Sobre o "primeiro governante", Al-Fârâbî discorre nas seções 7-9, 14b e 18 do Livro sobre a Religião (AL-FÂRÂBî, 2004², p. 98-99; 104; 107). Contudo, Al-Fârâbî distingue claramente o primeiro governante de seu sucessor (AL-FÂRÂBÎ, 2004², seção 14b, p. 104; AL-FÂRÂBî, 1992, seção 5, p. 85). O segundo governante é indicado pelo título de al-mâlik al-sunna.

${ }^{7} \mathrm{O}$ termo árabe ârâ' (pl.) (sing. ra'y), que significa "opiniões", é parte do título da obra de Al-Fârâbî, Princípios acerca das Opiniões dos Habitantes da Cidade Virtuosa (Mabâdi' ârâ' ahl al-madînat alfâdila), e diz respeito aos princípios gerais que formam a base das crenças de uma religião (GUERRERO, in: AL-FÂRÂBÎ, 1992, p. 73, nota 2). Al-Fârâbî examina as "opiniões" no cap. I, seção 2, do Livro sobre a Religião (Kitâb al-Milla) (AL-FÂRÂBÎ, 1992, p. 75; AL-FÂRÂBÎ, 2004², p. 94).
} 
cidade "ignorante" viviam no estado de ignorância e, por isso, não conheciam as virtudes ${ }^{8}$. Quanto às ações a serem cumpridas, seu sucessor seguirá o exemplo dado pelo fundador da religião. Seu governo será sempre baseado na tradição legal (sunna) e seu título será o de governante ou de rei da tradição legal (mâlik al-sunna ${ }^{9}$ ) (AL-FÂRÂBî, 1992, p. 85; id., 2004²a, p. 104).

No capítulo 15, §12, da edição de Richard Walzer de Princípios acerca das Opiniões dos Habitantes da Cidade Virtuosa (Mabâdi' ârâ' ahl al-madînat al-fâdila), em relação ao "primeiro governante" (al-ra'îs al-awwal) ou governante virtuoso, Al-Fârâbî declara que o chefe "[...] de toda a parte habitada da terra", entenda-se o Império Islâmico, deve ser dotado de doze qualidades inatas (AL-FÂRÂBÎ, 1998², p. 246). Essas qualidades são herdadas das linhas iniciais do Livro VI da República, cuja referência direta está no tratado Obtenção da Felicidade (Tahsîl al-sacâda), em que Al-Fârâbî afirma que Platão prescreveu as qualidades exigidas para o filósofo "[...] na República (fî al-Siyâsa)" (AL-FÂRÂBî, 2001³ , p. 48). Nessas duas obras de Al-Fârâbî, porém, a disposição e o número das qualidades diferem ligeiramente. No tratado sobre as Opinióes dos Habitantes da Cidade Virtuosa, a lista das qualidades exigidas do governante é a seguinte:

1. Possuir membros e órgãos livres de qualquer deficiência e tão fortes que possa executar facilmente qualquer ação que deles dependa ${ }^{10}$.

2. Ser, por natureza, dotado de uma inteligência aguda e da capacidade de compreender perfeitamente tudo sobre o que se fala, de modo a apreender o sentido visado por seus interlocutores e de acordo com o que desejavam exprimir ${ }^{11}$.

3. Ser capaz de reter tudo o que venha a conhecer, ver, ouvir, ou seja, deve ter excelente memória para não se esquecer do que apreendeu ${ }^{12}$.

\footnotetext{
${ }^{8}$ Clara alusão à missão do profeta fundador do Islã, Muhammad, e ao "tempo da ignorância" (jâhiliyya), isto é, ignorância da Unicidade de Deus, dos anjos, da profecia, do julgamento final e das bemaventuranças e tormentos na vida depois da morte.

${ }^{9}$ Segundo Richard Walzer, al-mulk al-sunnî, o governo de acordo com as leis, poderia ser aplicado a qualquer califa "bom", isto é, o que segue a Tradição (a sunna determinada pelo Corão e pelas compilações dos hadîths) (WALZER, in: AL-FÂRÂBÎ, 1998², p. 448-449). Contudo, acreditamos que Al-Fârâbî se refira a Abû Bakr, primeiro califa e sucessor de Muhammad.

${ }^{10}$ Em Rep. VI, 494b 6, Platão observa que a saúde e o preparo físico são indispensáveis: “[...] as qualidades naturais do corpo devem corresponder às da alma", ou seja, a perfeição do corpo deve acompanhar a perfeição da alma; em Rep. 498b 5, Platão afirma a necessidade de que os jovens cuidem bem de seus corpos. Para Al-Fârâbî, a perfeita condição física é condição necessária para o comandante supremo dos exércitos e condutor dos muçulmanos.

${ }^{11}$ Ver Rep. VI, 486c 3; 490c 11: eumathês.

${ }^{12}$ Ver Rep. VI, 486c-d; 490c 11; 494b 2
} 
4. Ter o espírito tão sagaz e penetrante que lhe baste, para apreender algo, o menor indício a respeito ${ }^{13}$.

5. Ser dono de uma boa eloquência, para que possa enunciar com perfeita clareza tudo o que concebeu em sua mente ${ }^{14}$.

6. Amar a instrução e o aprendizado, e a isto deve estar facilmente predisposto, sem fadiga nem prejuízo do esforço despendido ${ }^{15}$.

7. Amar a verdade e os que são verdadeiros, odiar a falsidade e os mentirosos ${ }^{16}$.

8. Não ser ávido no comer, no beber e no prazer carnal, evitando naturalmente o jogo e detestando os prazeres que disso derivam ${ }^{17}$.

9. Ter grandeza de alma (kabîr al-nafs) ${ }^{18}$ e honorabilidade para que sua alma permaneça com naturalidade acima das vilanias e tenda sempre para as coisas nobres ${ }^{19}$

\section{Desprezar o ouro e a prata e todos os bens terrenos ${ }^{20}$.}

11. Amar naturalmente a justiça e os justos e odiar a injustiça, a tirania e os que as cometem; ser equânime para com os seus e os outros, incitando-os nesse sentido; compensar as vítimas da injustiça, dando a todos tudo o que ele próprio estima bom e belo; ser probo e dócil, não devendo ser nem

\footnotetext{
${ }^{13}$ Hads (poderia corresponder ao grego ankhinoía?). Não há na República um paralelismo óbvio desse conceito que surge na filosofia de expressão árabe. Para Avicena, o intelecto santo recebe os inteligíveis diretamente do mundo celeste, ou melhor, da inteligência agente, porque possui uma intuição/ sagacidade (hads), que lhe permite fazer contato direto com essa inteligência. A intuição/sagacidade (hads) de Avicena pode estar ancorada no conceito de ankhinoía (sagacidade) de Aristóteles (Anal Post. I, 34, 89b)

${ }^{14}$ Certamente a boa eloquência deriva da Retórica, de Aristóteles.

${ }^{15}$ Ver Rep. VI, 485b.

${ }^{16} \mathrm{O}$ amor à verdade e o ódio à falsidade estão entre as mais nobres qualidades platônicas, cf. Rep. VI, 485c 3; 485d.

${ }^{17}$ Não bastam as qualidades intelectuais, se as qualidades morais não forem desenvolvidas desde a infância; a intemperança deve ser contida, pois o futuro governante não deve ser dado aos prazeres dos sentidos, deve ser um sóphron; ver Rep. VI, 485c 3; 490b 5.

${ }^{18}$ Corresponde a megalopsykhós e megalopsykhía, termos que denotam a mais alta perfeição moral na ética aristotélica; o megalopsychós é alguém dotado de uma grande perfeição moral; sobre megalopsykhía, ver a definição de Aristóteles em Ét. Nic. IV, 7, 1124a 1 (Cf. WALZER, in: AL-FÂRÂBî, 19982, p. 446).

${ }^{19} \mathrm{Na}$ República, Platão usa o termo megaloprepés, expressão que no Perípato passou a designar alguém generoso com dinheiro; ver Ét. Nic. IV, 4, 1122a 19-30: “(megaloprépeia) é um tipo de virtude que diz respeito às riquezas [...] quanto aos gastos [...]". Aristóteles distingue a generosidade com o dinheiro da magnanimidade.

${ }^{20}$ Ver Rep. VI, 485e 3: dinheiro e bens materiais não devem interessar ao governante-filósofo, o qual não deve ser philokhrématos.
} 
obstinado nem teimoso, quando se tratar de ser justo, mas inflexível, quando lhe for pedido que cometa uma injustiça ou vilania ${ }^{21}$.

12. Ter vontade firme, decidida e audaciosa para, sem medo nem fraqueza, empreender o que considera que deva ser realizado ${ }^{22}$.

As cinco qualidades intelectuais necessárias ao futuro governante $(2,3$, $4,5,6)$ e as cinco qualidades morais $(7,8,9,10,11)$ estão listadas na ordem de importância, primeiro as intelectuais e depois as morais, todas elas encabeçadas pela primeira condição necessária ao governante, a de ter um corpo perfeito, sem defeitos ${ }^{23}$. A última, a coragem (ou disposição firme e decidida de realizar o que for necessário, sem medo nem fraqueza), fecha a lista.

Al-Fârâbî põe em primeiro lugar a integridade física, porque é evidente que, sem ela, não há como desenvolver as qualidades intelectuais mencionadas em seguida. Do mesmo modo, parece que, sem as qualidades intelectuais, não há como desenvolver as qualidades morais. A última da lista, a coragem, condição necessária a um chefe de governo para manter a ordem e defender a cidade dos ataques inimigos, é a única que se refere exclusivamente a uma situação social, pois todas as outras podem, muito bem, ser ainda aplicadas a um cidadão comum, sem que necessariamente ele venha a ser um chefe de governo. São as qualidades intelectuais e morais que se aplicam a um filósofo e que, numa visão mais ampla, podem bem servir de parâmetro para uma reforma global da sociedade. Contudo, essa consideração não está explicitamente presente em Al-Fârâbî, já que nessa passagem o seu interesse se dirige à figura do governante.

Com poucas diferenças, as qualidades arroladas no tratado sobre a Cidade Virtuosa são repetidas no opúsculo Obtenção da Felicidade. Segundo Hans Daiber, parece que a lista farabiana apresentada na Cidade Virtuosa é um sumário tardio de discussões derivadas de outros trabalhos de Al-Fârâbî (DAIBER, 1986, p. 6 [134]). Em Obtenção da Felicidade, a lista é ligeiramente diferente da que Al-Fârâbî apresenta na Cidade Virtuosa, mas igualmente tira sua inspiração da mesma passagem da República e está mais próxima do texto platônico.

${ }^{21}$ A justiça é tão importante para Al-Fârâbî como o é para Platão, e isso fica evidente pelo modo como Al-Fârâbî se estende ao descrever essa qualidade essencial do governante; ver Rep. VI, 486b 10; 490b 5.

${ }^{22}$ Referência à platônica andreía (coragem).

${ }^{23}$ É interessante observar que Platão menciona a perfeição física (Rep. VI, 494b 6; 498b 5) só depois de alertar sobre a exigência de facilidade do aprendizado, de boa memória, de ser corajoso e magnânimo. 
Em Obtenção da Felicidade, antes de listar as qualidades essenciais ao governante, Al-Fârâbî discorre sobre a necessidade de ele ser também um filósofo, introduzindo a identificação do filósofo com o príncipe, legislador e imã:

Que fique claro que a ideia de filósofo, de governante supremo, de príncipe, de legislador e de imã é uma só ideia. Não importa qual dessas palavras tomares, se procurares encontrar o que cada uma delas significa para a maioria dos que falam a nossa língua, constatarás que, no final, todos estarão de acordo em dar [a esses termos] o significado de uma única e mesma ideia. (AL-FÂRÂBÎ, 2001³, p. 47, §58).

Na doutrina de Al-Fârâbî, o profeta, além de receber a Revelação, tem também a função de chefe e condutor da cidade. O homem, animal social antes de tudo, vive em grupos mais ou menos extensos, porém necessários para a sua sobrevivência; uma vez assentada, porém, a associação entre os homens deve abranger toda a terra habitada. Para ser perfeita, essa sociedade universal deve formar um só corpo, cujos membros, sob a direção de um único chefe - princípio de direção, de ordem e de equidade -, cumprirão cada qual a sua parte nas tarefas em que suas aptidões sobressaem.

Na cidade, o papel do chefe é preponderante. Assim como o universo é regido pela razão universal, e o homem, por sua própria razão, a cidade perfeita é regida por um guia impecável e infalível. Constata-se, com Al-Fârâbî, que a universalidade da razão se justapõe à da missão profética. Assim, esse chefe, que é modelo a ser por todos imitado, vem a ser ainda o legislador ideal que tanto promulga as leis, quanto consigna a cada um o seu lugar num conjunto harmonioso e justo. A cidade perfeita, porém, não é em si mesma um fim. Sua vasta associação tem por fim o encaminhamento do homem rumo à salvação e à felicidade na vida futura, uma vez que isolado, fora da religião e da sociedade, não saberia realizar a plenitude de seu ser (LAOUST, 1965, p. 420).

Identificados governante e filósofo, Al-Fârâbî passa a listar as qualidades essenciais e necessárias ao filósofo, "[...] as condições prescritas por Platão na República", que diferenciam o verdadeiro do falso filósofo (ALFÂRÂBÎ, 20013, p. 48):

1. Distinguir-se na compreensão e na concepção do que é essencial.

2. Ter boa memória e saber enfrentar o grande esforço que o estudo requer.

3. Amar a verdade e as pessoas verdadeiras, amar a justiça e os justos.

4. Não ser nem obstinado nem polemista quanto às coisas que deseja.

5. Não ser glutão com alimentos e bebidas e, por disposição natural, desdenhar os apetites, o dinheiro e coisas afins.

6. Ter nobreza de espírito e evitar o que é considerado indigno. 
7. Ser piedoso, ceder facilmente ao bem e à justiça, rechaçar o mal e a injustiça.

8. Ser determinado em favorecer as coisas justas e retas.

9. Ser educado de acordo com as leis e costumes que dizem respeito à sua disposição inata.

10. Ter convicção absoluta nas opiniões da religião em que foi criado e manterse firme na prática dos atos virtuosos dela; manter-se firme na prática das virtudes geralmente aceitas e não ignorar os atos nobres geralmente aceitos.

Com exceção da quarta e da décima condições, todas as restantes procedem do discurso platônico. A décima é certamente uma alusão à obediência dos preceitos islâmicos. A nona é derivada do discurso platônico de que a natureza nobre do filósofo só pode vingar se ele receber uma educação voltada para as virtudes mencionadas, pois, sem a educação apropriada, a melhor das naturezas é destruída e corrompida (Rep. VI, 494 b-495b). Al-Fârâbî reformula essa exigência platônica, acrescentando que o filósofo-governante deverá ser educado nas leis e nos costumes "[...] que dizem respeito à sua disposição inata", ou seja, nascido com uma natureza predisposta à virtude, ele deverá desenvolver as virtudes essenciais dentro dos limites das leis e costumes de sua sociedade, no caso, a islâmica.

Al-Fârâbî informa que essas qualidades físicas, morais e intelectuais constam do Livro VI, seção 1, da República, e foram por ele arranjadas de modo mais sistemático.

As qualidades essenciais ao governante em Averróis

No Livro I do Comentário sobre a República ${ }^{24}$, Averróis alude às qualidades essenciais ao governante e anuncia que discorrerá depois sobre elas:

Explicaremos depois as outras condições a respeito das virtudes morais e especulativas que os príncipes devem ter. Com efeito, os príncipes em tal cidade (isto é, a ideal) são sem dúvida os sábios em quem estão reunidas, junto com a ciência, estas virtudes e as outras, tal como as enumeraremos depois. (Trad. Elia Del Medigo I <XVIII, 4>; trad. Rosenthal I.xviii.4; trad. Lerner 39:24-28; trad. Cruz Hernández, p. 35).

\footnotetext{
${ }^{24}$ As edições do Comentário sobre a República que aqui usamos são as seguintes: Averróis (Ibn Rušd), 1992 (trad. Elia Del Medigo); 1966 (trad. Rosenthal); 1974 (trad. Lerner); $1990^{2}$ (trad. Cruz Hernández). A tradução latina (a partir da versão hebraica) de Elia Del Medigo foi realizada no século XV, possivelmente a pedido de Pico della Mirandola, com quem Del Medigo mantinha um intenso intercâmbio intelectual. O original árabe desse tratado de Averróis foi perdido, como grande parte de sua obra. Restam, todavia, as traduções medievais para o hebraico e para o latim.
} 
No Livro II, Averróis passa a desenvolver o tópico sobre as qualidades necessárias ao governante. Antes, porém, ele define o significado de governante:

Ora, "rei" significa, em sentido próprio, "senhor das cidades". É manifesto que a arte pela qual é senhor e governa as cidades completa-se quando nele estiverem reunidas todas essas condições. A disposição em relação ao legislador é semelhante, ainda que este nome signifique, em primeiro lugar, aquele em quem está presente a virtude cogitativa pela qual são descobertas as coisas operativas sobre os povos e cidades. Ora, ele próprio precisa daquelas condições. Por isso, esses nomes, a saber, "filósofo", "rei" e "legislador", são quase sinônimos. De modo semelhante, "sacerdote" (imâm ${ }^{25}$ ), porque, em árabe, "sacerdote" (imâm) designa aquele em quem se confia quanto a suas ações. É "sacerdote" (imâm) pura e simplesmente aquele em quem se tem confiança quanto a suas ações pelas quais é filósofo. (Trad. Elia Del Medigo II $<$ I, 5-6>; trad. Rosenthal II.1.5-6; trad. Lerner 61:8-17; trad. Cruz Hernández, p. 72).

Essas considerações são uma clara remissão ao tratado de Al-Fârâbî Obtenção da Felicidade:

$\S 57$ [...] a ideia de imâm, filósofo e legislador é uma única ideia. Contudo, o nome filósofo significa primariamente virtude teorética. Porém, se está determinado que a virtude teorética atinge a sua perfeição última em qualquer referência, segue necessariamente que ele precisa possuir também todas as outras faculdades. Legislador significa excelência de conhecimento concernente às condições de inteligíveis práticos, a faculdade para encontrá-los e a faculdade de levá-los a efeito nas nações e cidades. Quando estiver determinado que elas sejam trazidas à existência com base no conhecimento, segue que a virtude teorética precisa preceder as outras - a existência de inferiores pressupõe a existência dos mais altos. O nome príncipe significa soberania e habilidade. Para ser absolutamente capaz, ele deve ter o poder de uma maior habilidade. A sua habilidade para perfazer algo não pode resultar apenas de coisas externas; ele próprio deve possuir grande habilidade porque a sua arte, perícia e virtude são de um poder extraordinariamente grande. Isso não é possível a não ser com grande poder de conhecimento, grande poder de deliberação e grande poder de virtude [moral] e arte. De outro modo, ele não é nem verdadeiramente capaz nem soberano. Pois, se a sua habilidade cessar perto disto, ela é ainda imperfeita. De modo

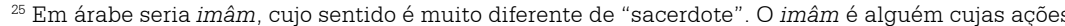
são o modelo para a reta conduta. Recobre o sentido de líder militar, líder da oração e, mais importante, líder da comunidade islâmica, no caso, o califa. Elia Del Medigo traduziu o hebraico kahanî para "sacerdote", que, no entanto, tem duas acepções, tal como explicamos, em seguida, no corpo do texto.
} 


\begin{abstract}
semelhante, se sua habilidade for restringida a bens inferiores à felicidade suprema, a sua habilidade é incompleta e ele não é perfeito. Por essa razão, o verdadeiro príncipe é o mesmo que o filósofo-legislador. Quanto à ideia de imâm, na língua árabe significa simplesmente aquele cujo exemplo é seguido e é bem recebido, ou seja, ou a sua perfeição é bem recebida ou o seu propósito é bem recebido. Se não for bem recebido em todas as infinitas atividades, virtudes e artes, então não é verdadeiramente bem recebido. Somente quando todas as outras artes, virtudes e atividades buscarem realizar o seu propósito e nenhum outro, a sua arte será a mais poderosa arte, a sua virtude, a mais poderosa virtude, a sua deliberação, a mais poderosa deliberação, e sua ciência, a mais poderosa ciência. Com todos esses poderes, ele estará explorando os poderes dos outros para completar o seu próprio propósito. Isto não é possível sem as ciências teoréticas, sem a maior de todas as virtudes deliberativas, e sem o resto daquelas coisas que tem o filósofo. §58. Portanto, que esteja claro para ti que a ideia de filósofo, governante supremo, príncipe, legislador e imâm é uma única ideia. Para qualquer uma dessas palavras, se procurares entre a maioria dos que falam a nossa língua o significado de cada uma delas, encontrarás que todos, no final, estão de acordo em dar a elas o significado de uma mesma ideia. (AL-FÂRÂBî, 2001³, p. 46-47).
\end{abstract}

Retomando a última passagem citada do Comentário sobre a República, Averróis afirma que o termo "rei", em seu sentido originário, concerne aos que governam as cidades. Acrescenta, em seguida, que é evidente que a arte de governar só se perfaz se todas as condições requeridas do governante nele estiverem combinadas. Nesse momento, essas condições não são ainda mencionadas, mas Averróis lembra que, a respeito do "legislador", foi esse o caso, isto é, nele estavam todas as condições combinadas. Na sequência, Averróis observa que, embora o termo "legislador" indique alguém dotado da virtude cogitativa, "[...] por meio da qual são descobertas as coisas práticas sobre os povos e governos" (Trad. Elia Del Medigo II $<$ I, 6>; trad. Rosenthal II.i.6; trad. Lerner 61:3-4; trad. Cruz Hernández, p. 72)26 o governante necessita também das outras condições (que serão indicadas mais adiante). É possível que, ao mencionar o legislador, Averróis esteja referindo-se ao Profeta Muhammad ${ }^{27}$, porque, algumas linhas depois, salienta que a condição

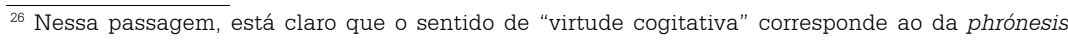
aristotélica, pois é phrónimos quem sabe bem deliberar sobre o que é mais útil e bom para si e para os outros; cf. Aristóteles. Ética Nicomaqueia VI, 5, 1140a 25 - 1140b 30. Esse tema foi desenvolvido em minha tese de doutorado (ver PEREIRA, 2008), cuja publicação está no prelo na Editora Perspectiva.

${ }^{27}$ Essa frase, no entanto, é muito ambígua, pois se sabe que, para os muçulmanos, a Lei revelada foi dada por Allâh, sendo Ele o Legislador supremo. Contudo, o legislador a que se refere Averróis pode ser o jurisconsulto que interpreta a Lei divina e os dizeres do Profeta, e contribui para a formação do corpo legal das normas a serem estabelecidas, como é o caso das escolas jurídicas (madhâhib) ortodoxas.
} 
de ser profeta exigida para o governante merece uma investigação mais aprofundada (Trad. Elia Del Medigo II <I, 7>; trad. Rosenthal II.i.7; trad. Lerner 61:17-18; trad. Cruz Hernández, p. 72).

Na sequência dessa sucinta passagem, Averróis enfatiza que esses nomes, a saber, filósofo, rei, legislador, são quase sinônimos. E, igualmente, o termo "sacerdote" (imâm), porque, em árabe, a ideia de "sacerdote" (imâm) designa aquele em quem há confiança, visto que é sábio e é seguido em seus atos e obras (Trad. Elia Del Medigo II <I, 6>; trad. Rosenthal II.i.6; trad. Lerner 61:14-17; trad. Cruz Hernández, p. 72) ${ }^{28}$

A menção a um governo "sacerdotal", na versão latina do Comentário sobre a República, apresenta um problema: qual teria sido o termo original árabe que, passando para a versão hebraica, deu origem, na tradução latina, à expressão "governo sacerdotal"?

Em sua tradução do hebraico para o latim, Elia Del Medigo verteu o adjetivo kahanî (ou kohanî, conforme a pronúncia) por "sacerdotal", porque uma das acepções do termo é a bíblica, que se refere a alguém destinado a ser sacerdote. Há, porém, um segundo significado, o que se relaciona a alguém de posição elevada. Este último é o significado primário no texto de Averróis que comenta a República e em que não há qualquer menção a uma classe sacerdotal. Corresponde, portanto, ao termo árabe imâm, que designa aquele que está à frente, que conduz, que lidera. De origem pré-islâmica, o título de imâm, que mais tarde seria o título oficial dos califas, pertencia ao chefe da tribo. Com o sentido geral de líder, imâm passou a designar igualmente aquele que conduz as orações; pode ainda indicar o chefe de um grupo militar, mas o principal e mais importante apelativo é dado ao califa, chefe da comunidade dos muçulmanos (LAMBTON, 19913, p. 331-333) ${ }^{29}$.

Voltemos ao Comentário sobre a República: como já foi exposto o que vem a ser um filósofo e já está posto que apenas os filósofos estão aptos para governar, Averróis passa a enumerar as qualidades "naturais" necessárias para o soberano, que deve tornar-se também um filósofo.

Uma delas, a mais apropriada, é que ele esteja naturalmente apto a acrescentar ao seu aprendizado as ciências especulativas. E isto ocorre quando, por sua natureza, for conhecedor daquilo que é por si e o distingue daquilo que é por acidente.

\footnotetext{
${ }^{28}$ Comparar com Al-Fârâbî, 2001³, p. 46, §57; p. 47, §58.

${ }^{29}$ Em Mabâdi' ârâ' ahl al-madînat al-fâdila (Princípios acerca das Opiniões dos Habitantes da Cidade Virtuosa), Al-Fârâbî afirma que o soberano supremo é imâm (AL-FÂRÂBî, 1998², p. 24, §11 [texto árabe, p. 246])
} 
Em segundo lugar, que tenha uma memória que guarde bem e que não seja instável e esquecidiça, pois quem não tem essas duas condições, não lhe é possível acrescentar algo mais [ao que já sabe]. De fato, ele não deixa de estar num esforço contínuo, posto que não renuncia ao estudo e à leitura.

Terceiro, que ame e escolha a instrução e que esta lhe pareça ser admirável em todas as partes da ciência, pois, como se diz, desejando muito alguma coisa, deseja-se todas as espécies dela. Por exemplo, quem ama o vinho ama todos os vinhos e, do mesmo modo, quem ama as mulheres.

Quarto, que ame a verdade e a justiça e odeie a falsidade e a mentira, pois quem ama o conhecimento dos entes conforme o que são é amante da verdade. Ora, o amigo da verdade é inimigo da mentira e, por isso, não ama a mentira.

Quinto, que despreze os apetites dos sentidos, pois quem tem um apetite muito intenso de alguma coisa afasta sua alma dos demais apetites, e assim é a disposição que há neles (isto é, nos filósofos), uma vez que entregaram toda a sua alma ao ensino.

Sexto, que não seja ávido de dinheiro, pois o dinheiro é um apetite. Ora, os apetites não convêm a tais homens.

Sétimo, que seja magnânimo (isto é, que tenha grandeza de alma) e deseje conhecer tudo e todos os entes. A quem não parece ser suficiente conhecer a coisa quando surge à primeira vista é muito magnânimo e, por isso, tal alma não tem comparação com as outras.

Oitavo, que seja corajoso, porque aquele que não tem coragem não pode repelir e odiar aquilo em que foi educado por discursos não demonstrativos, sobretudo aquele que foi educado nessas cidades ${ }^{30}$

Nono, que esteja apto a mover-se por si próprio para a coisa que é vista por ele ser boa e bela, como a equidade e outras virtudes, e isto porque sua alma apetitiva é intensamente fiel à razão e à cogitação.

Acrescente-se a estas [condições] que tenha boa retórica com que possa proclamar facilmente qualquer coisa sobre a qual cogite e, com isso, seja sagaz e saiba encontrar o termo médio rapidamente. Estas são as condições da alma que são exigidas nesses homens.

As condições corporais, porém, são as já expostas a respeito dos guardiões: boa estrutura do corpo, destreza e boa preparação. (Trad. Elia Del Medigo II $<$ II, 2-12>; trad. Rosenthal II.ii.2-12; trad. Lerner 61:23-62:21; trad. Cruz Hernández, p. 73-74).

\footnotetext{
${ }^{30}$ Com essa afirmação, parece que Averróis esteja se referindo à necessidade de o soberano saber se opor corajosamente às afirmações dos teólogos, pois a frase que indica que deve saber enfrentar os argumentos não demonstrativos com que cresceu, especialmente se cresceu "nessas cidades", remete principalmente às teses expostas em seu Tratado Decisivo contra os argumentos dos teólogos (mutakallimûn) que desvirtuam o ensinamento da Lei revelada e à polêmica tecida em seu Tahâfut al-Tahâfut (Demolição da Demolição), obra destinada a refutar as teses que o teólogo Al-Ghazâlî defendeu contra os filósofos.
} 
Simplificadas, as qualidades da alma podem resumir-se no seguinte:

1. Disposição natural para o aprendizado das ciências teoréticas.

2. Ter boa memória.

3. Amar o conhecimento.

4. Amar a verdade e a justiça e odiar a falsidade.

5. Ser temperante (moderado).

6. Desprezar o dinheiro (bens materiais).

7. Ser magnânimo, ou melhor, ser aberto para receber o conhecimento de tudo.

8. Ser corajoso para enfrentar opiniões consolidadas, mas não fundamentadas na ciência.

9. Ser justo e virtuoso com base na razão.

10. Ter boa retórica para expor os argumentos fundados na ciência e ter habilidade para encontrar rapidamente o termo médio.

Observe-se que as qualidades 1, 3, 4, 7 e 10 aplicam-se à figura do sábio-filósofo; as qualidades 5, 6 e 9 são morais; a oitava define a coragem em termos de um enfrentamento no nível da argumentação contrária à ciência. A segunda, a boa memória, é um requisito tradicional desde Platão, Al-Fârâbî e o jurista Al-Mawardî. A última qualidade da lista, a boa retórica, não é mencionada por Platão, mas faz parte da tradição islâmica recebida por Averróis. Além disso, essa qualidade, no pensamento de Averróis, é essencial para o ensino das massas, conforme está exposto no Tratado Decisivo. Como, em seguida, Averróis menciona a habilidade para encontrar o termo médio, certamente tem em mente o silogismo retórico ou entimema. Todavia, nada impede que esteja se referindo ao silogismo apodítico. De qualquer modo, para Averróis, a boa retórica são os discursos que têm por base a ciência.

Além de mudar a ordem em que Platão as cita, Averróis adapta as qualidades arroladas na República. Assim, por exemplo, a primeira qualidade coincide em parte com a platônica, pois Averróis a enuncia sob o prisma da filosofia aristotélica, afirmando que o filósofo deve saber distinguir o necessário do contingente. E a terceira, uma sequência da primeira, na medida em que são citadas as partes da filosofia, remete à clássica divisão das ciências entre teoréticas e práticas e suas subdivisões.

A coragem é necessária para o embate com ideias, e não com armas. Somos levados a crer que Averróis se refira, sobretudo, aos debates com os teólogos, questão sempre presente em seus tratados considerados polêmicos, posto que a frase sobre os que foram especialmente educados "nessas cidades" é uma clara crítica à sociedade de seu tempo. 
A magnanimidade é compreendida como grandeza de espírito para acatar tudo o que a ciência concebe como verdadeiro, impedindo, desse modo, que o pensamento permaneça confinado às opiniões que não resistem ao escrutínio científico. Donde, o que parece à primeira vista verdadeiro só pode ser considerado verdadeiro se demonstrado apoditicamente. Essa é a tese principal do Tratado Decisivo, em que Averróis afirma a importância da demonstração para o conhecimento das verdades enunciadas na Lei revelada, contra a argumentação dialética dos teólogos.

O amor à verdade está a par com o amor à justiça, já que não há verdade sem justiça. Esse amor à verdade e à justiça é o amor ao conhecimento dos entes conforme o que são, portanto, amor ao conhecimento especulativo. Surpreende que Averróis não faça qualquer menção à justiça propriamente. Talvez porque aqui ele esteja arrolando as qualidades essenciais ao filósofo e a justiça seja vista apenas em relação à posse do conhecimento. Mas, como ele identificou, para a condução da cidade, os termos filósofo, rei, legislador e imã, causa certa perplexidade o fato de não ter concedido maior destaque à justiça, ele que foi um cádi atuante. A justiça, ou equidade, é novamente mencionada a respeito do sábio, cuja alma apetitiva é controlada pela razão, quando ele vai em direção do bem e do belo. Dessa maneira, a justiça aparece, no elenco das qualidades, como algo que só é obtido por meio do conhecimento teorético, embora possamos inferir que o conhecimento do bem supremo, isto é, a felicidade, seja o conhecimento teórico da ciência prática política, ou seja, a ética. Aqui, portanto, a justiça estaria a par com a felicidade.

Quanto à temperança ou moderação, é mencionada em qualidades separadas, no controle dos apetites sensoriais e na censura à cupidez pelo dinheiro. Uma vez que a usura é condenada pelo Corão, talvez Averróis conceda um certo destaque à necessidade de controle dessa tendência.

$$
\star * *
$$

Embora tivesse conhecimento da existência do tratado aristotélico Política, Averróis afirma não ter tido a oportunidade de conhecê-lo diretamente, justificando assim o fato de ter-se debruçado sobre a República para compor um tratado cujo campo de estudo é a parte prática da política. Em dois momentos ${ }^{31}$ de seu Comentário sobre a República, porém, Averróis declara aterse aos argumentos científicos da ciência política e deixar de lado os dialéticos. Com isso, ele parece estar advertindo que não seguirá fielmente a obra de Platão, ao contrário de sua praxe nos comentários sobre as obras de Aristóteles.

${ }^{31}$ A base teorética da ciência política é anunciada no início e confirmada no final do tratado: Início (Preâmbulo): Trad. Elia Del Medigo I <I, 1>; trad. Rosenthal I.i.1; trad. Lerner 21.1; trad. Cruz Hernández, p. 3 - Trad. Elia Del Medigo I <I, 9>; trad. Rosenthal I.i.9; trad. Lerner 22.9; trad. Cruz Hernández, p. 3; Final: Trad. Elia Del Medigo III <XXI, 2>; trad. Rosenthal III.xxi.2; trad. Lerner 105.9; trad. Cruz Hernández, p. 148 - Trad. Elia Del Medigo III <XXI, 5>; trad. Rosenthal III.xxi.5; trad. Lerner 105.25; trad. Cruz Hernández, p. 149. 
É evidente a importância dada por Averróis à figura do soberanogovernante em seu Comentário sobre a República. Ainda que essa obra contenha propostas para a criação de uma sociedade que se aproxime daquela descrita por Platão na República, no desenvolvimento de sua exposição sobre as virtudes, Averróis conduz seu leitor à conclusão de que a phrónesis aristotélica deve ser a virtude específica do governante. Não se trata mais de uma sabedoria (sophía) platônica voltada para o mundo das Ideias transcendentes, mas de uma sabedoria prática (phrónesis), tal como foi elaborada por Aristóteles na Ética Nicomaqueia. No Comentário sobre a República, a virtude cogitativa, ou seja, phrónesis e seu corolário, boúleusis e prohaíresis (deliberação e escolha deliberada), é a excelência que, aliada à experiência e às virtudes morais, é essencial para o desempenho do governante ideal, de acordo com a ética de Aristóteles, em que Péricles é apresentado como o paradigma do bom governante, que busca o bem para si e para os outros. O bem é conhecido pela ética e, com a reta prática, realiza-se na cidade ideal. Sem deixar de lado a excelência especulativa necessária ao bom governante, Averróis, ao dar destaque à virtude cogitativa (phrónesis), defende a ideia de que é esta a virtude essencial à arte de governar. Como a arte de governar tem dois lados, o teórico e o prático, ou seja, a ética e a política, o bom governante deve conhecer a parte teórica para bem exercer a parte prática da política. Esta é a concepção de ciência política de Averróis que, no Comentário Médio à Ética Nicomaqueia, afirma que "[...] a prudência e a arte de governar as cidades são um único campo de investigação (subiecto)"32.

O leitor, contudo, poderá espantar-se ao não encontrar, na lista de Averróis, a sabedoria prática entre as primeiras qualidades necessárias ao governante-filósofo. No entanto, a terceira qualidade exige o amor ao estudo e o desejo de conhecer todas as partes da ciência, o que indica a necessidade do conhecimento da filosofia prática, além da especulativa. A nona qualidade, porém, é mais específica, pois indica a disposição do soberano para dirigirse ao que ele considera bom e belo, se seguir a razão e a cogitação.

Ainda que faça menção ao bem e ao belo - noções encontradas na República -, a exigência de que o governante-filósofo saiba por si só discernir o bem e o belo remete à ideia do phrónimos, para quem é essencial fazer uma boa deliberação (euboulía) para tomar uma reta decisão (prohaíresis). $\mathrm{E}$, se o governante-filósofo sabe discernir o que é bom e belo, é porque segue fielmente os ditames da razão e da cogitação (phrónesis).

\footnotetext{
${ }^{32}$ Averrois Cordubensis expositione Aristotelis Stagiritae, Peripateticorum Principis Moralium Nicomachiorum. In: Aristotelis Opera cum Averrois Commentariis. v. III. Venetiis, apud Junctas 15621574. Reprodução anastática: Frankfurt am Main: Minerva G.m.b.H., 1962, fol. 87, cap. 8: "Das partes da prudência".
} 
Embora comente uma obra de Platão e, reiteradas vezes, recorra a enunciados tomados da obra de Al-Fârâbî, Averróis tem como proposta principal trazer seu leitor para o que ele considera a "verdadeira filosofia", ou seja, a de Aristóteles. Ao "aristotelizar" a República, o Comentador permanece fiel a seu projeto.

PEREIRA, R. H. S. Plato, Al-Fârâbî and Averroes: the ruler's essencial qualities.Trans/ Form/Ação, (Marília); v.34, n.1, 2011, p.1-20.

ABSTRACT: The political philosophy that developed in the Islamic world between the 9th and 12th centuries assumed ideas from Greek philosophy, mainly from Plato and Aristotle. Plato's Republic and Laws, and Aristotle's Nicomachean Ethics were the texts that laid the foundation for the political conceptions of the Arab philosophers, from the virtues to be sought after individually, to the idea of the best political regime. Based on the Greek texts translated into Arabic, these philosophers outlined the aims of political life, and the manner in which the political regime should be structured to achieve these aims. The ideal Platonic city is the paradigm to be realized. The topic of the ruler's essential qualities is part of a long tradition which remounts to the "mirrors of the princes" of Persian origin; it also appears in the Religious tradition and in the Islamic law. Two great exponents of the Arabislamic philosophy, Al-Fârâbî and Averroes, retrieved the topic of the ruler's essential qualities of the king-philosopher uttered in the Republic, and adapted it to their historical universe.

KEYWORDS: Plato. Fârâbî. Averroes. Ruler's qualities. Virtues.

\section{Referências}

AL-FÂRÂBÎ. Obras filosófico-políticas. Edição bilíngue árabe-espanhol. Edição, tradução, introdução e notas de Rafael Ramón Guerrero. Madrid: Debate-CSIC, 1992.

On the perfect state (Mabâdi' ârâ' ahl al-madînat al-fadilah). (19851). Edição bilíngue árabe-inglês. Revised text with Introduction, Translation, and Commentary by Richard Walzer. Oxford: Oxford University Press, $1998^{2}$.

The attainment of happiness (Tahsîl al-Sacâda). In: ALFARABI. Philosophy of Plato and Aristotle. (1962'1). Translated with an Introduction by Muhsin Mahdi. Revised Edition: Foreword by Charles E. Butterworth \& Thomas L. Pangle. Ithaca: Cornell University Press, 2001³. p. 13-50.

.The political writings. "Selected Aphorisms" and Other Texts. (20011). Translated and Annotated by Charles E. Butterworth. Ithaca: Cornell University Press, $2004^{2}$

AVERRÓIS (IBN RUŠD). Averroes' Commentary on Plato's 'Republic'. (1956¹). Edição bilíngue hebraico-inglês. Edited with and Introduction, Translation and Notes by E. I. J. Rosenthal. Cambridge: Cambridge University Press, reprint with correction, 1966. [cit. como "trad. Rosenthal"]. 
Averroes on Plato's "Republic". Translated, with and Introduction and Notes, by Ralph Lerner. Ithaca: Cornell University Press, 1974. [cit. como "trad. Lerner"].

Exposición de la "República" de Platón (Taljîs Kitâb al-Siyâsat Aflâtun). Estudio preliminar, traducción y notas de Miguel Cruz Hernandez. (1986 ${ }^{1}$. Madrid: Editorial Tecnos, 1990². [cit. como "trad. Cruz Hernández"].

Parafrasi della "Repubblica" nella traduzione latina di Elia del Medigo. Edição do texto latino por Annalisa Coviello e Paolo Edoardo Fornaciari. Firenze: Leo S. Olschki Editore, 1992. [cit. como "trad. Elia Del Medigo"].

DAIBER, Hans. The ruler as philosopher: a new interpretation of Al-Fârâbî's view. Nieuwe reeks, deel 49, $\mathrm{n}^{\circ}$ 4. Amsterdam: North Holland Publishing Company, 1986.

LAMBTON, Ann K. S. State and government in Medieval Islam: an introduction to the study of Islamic political theory: the jurists. (1981'1). Oxford: Oxford University Press, 19913.

LAOUST, Henri. Les shismes dans l'islam. Paris: Payot, 1965.

MAHDI, Muhsin. La cité vertueuse d'Alfarabi: la fondation de la philosophie politique en Islam. Paris: Albin Michel-Idées, 2000.

MELAMED. Abraham. The philosopher-king in medieval and renaissance jewish political thought. New York: State University of New York Press, 2003.

PEREIRA, Rosalie H. S. Averróis e a arte de governar: uma leitura aristotélica d'A República. 2008. Tese (Doutorado em Filosofia) - Instituto de Filosofia, Ciências Humanas, Universidade Estadual de Campinas, Campinas, 2008.

The ruler's essential qualities in Averroes' Commentary on Plato's "Republic". In: SYMPOSIUM PLATONICUM PLATO'S POLITEIA, 9, 2-7 August, 2010, Tóquio. Proceedings... Tóquio: Keio University, 2010. v. 2, p. 132-137.

PLATÃO. Lettre VII. In: . Oeuvres Complètes. Traduction nouvelle de E. Chambry. Paris: Librairie Garnier et Frères (Classiques Garnier), 1950. Tome VIII, p. 315-354.

La République. Tradução (francesa), introdução e notas de Georges Leroux. Edição aumentada e corrigida. Paris: Flammarion, (20021), $2004^{2}$.

. A República. Tradução (portuguesa) direta do grego de Anna Lia Amaral de Almeida Prado. Revisão técnica e introdução de Roberto Bolzani Filho. São Paulo: Martins Fontes, 2006.

STRAUSS, Leo. Quelques remarques sur la science politique de Maïmonide et de Fârâbî. Revue des Etudes Juives, v. 100 bis, p. 1-37, 1937. Reprint in: Maimonide. Paris: PUF, 1988. p. 143-182. 